\title{
What Iron Pipefittings Can Teach Us About Public and Private Power in the Market
}

\section{Sandeep Vaheesan}

sandeep.vaheesan@gmail.com

Follow this and additional works at: https://www.repository.law.indiana.edu/ilj

Part of the Antitrust and Trade Regulation Commons, and the Law and Economics Commons

\section{Recommended Citation}

Vaheesan, Sandeep (2016) "What Iron Pipefittings Can Teach Us About Public and Private Power in the Market," Indiana Law Journal: Vol. 91 : Iss. 5 , Article 3.

Available at: https://www.repository.law.indiana.edu/ilj/vol91/iss5/3

This Article is brought to you for free and open access by the Law School Journals at Digital Repository @ Maurer Law. It has been accepted for inclusion in Indiana Law Journal by an authorized editor of Digital Repository @ Maurer Law. For more information, please contact rvaughan@indiana.edu.

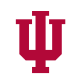

JEROME HALL LAW LIBRARY

INDIANA UNIVERSITY

Maurer School of Law
Blooming ton 


\title{
What Iron Pipefittings Can Teach Us About Public and Private Power in the Market
}

\author{
SANDEEP VAHEESAN ${ }^{*}$
}

Much of the current debate on competitive markets centers on whether state and local regulations that impede emerging industry competitors (such as Airbnb, Tesla, or Uber) and restrict occupational entry serve the public interest. This focus on government restraints on competition implicitly discounts private efforts to create closed markets - whether it is by the world's largest bookseller or the country's leading broadband provider. Listening to many politicians, lawyers, and economists talk these days, a layperson could be forgiven for assuming a competitive economy is one free from state intervention. ${ }^{1}$ But that is not the casestate actors establish the rules necessary for markets to function and thereby inevitably shape economic life. ${ }^{2}$ And sometimes, it is only through public intervention that competition can be maintained against private forces seeking to do away with it.

Furthermore, government regulations that limit market competition are not inherently harmful and can, in fact, advance important social goals. For example, "Buy American" rules can, by restricting competition from foreign producers, promote full employment in a depressed economy. Importantly, the government is (at least somewhat) responsive to popular and electoral pressure when making policy, often in the face of conflicting social goals. On the other hand, today's private empires, such as Amazon, Comcast, and Google, have the power, like Standard Oil and American Tobacco a century ago, to exclude competition and entrench their dominance to profit at the expense of the public. Unlike democratic governments, however imperfect, large corporations face little public accountability, and also few constraints in the marketplace. Monopolists and oligopolists do what is in their interests, regardless of the consequences for the rest of us.

Affirmed in April 2015 by the Eleventh Circuit, $^{3}$ the Federal Trade Commission's decision on the monopolization of the domestic iron pipefittings industry ${ }^{4}$ offers valuable insight on public and private power in the market. The fittings manufacturer, McWane, exploited the Buy American provision in the 2009 stimulus program to preserve a monopoly. The government restricted foreign competition on stimulus projects to help the ailing U.S. economy, while McWane closed the pipefittings market to bolster its own bottom line. This little-known episode suggests that academic and popular discussions are unduly cynical toward

\footnotetext{
* Member of the D.C. Bar; Duke University School of Law, J.D. May 2010; Duke University Graduate School Department of Economics, M.A. May 2010; University of Maryland, College Park, B.A. May 2005. I would like to thank Ken Davidson, Ben Douglas, Bert Foer, Lina Khan, Geoff Kozen, Barry Lynn, Steve McIntyre, Eugenie Montague, Chris Sagers, Bob Skitol, and Randy Stutz for their thoughtful comments on earlier drafts.

${ }^{1}$ Maurice E. Stucke, Better Competition Advocacy, 82 ST. JoHN's L. REV. 951, 954 (2008).

${ }^{2}$ See generally Bernard E. Harcourt, The Illusion of Free Markets: Punishment AND THE MYTH OF NATURAL ORDER (2011).

${ }^{3}$ McWane, Inc. v. FTC, 783 F.3d 814 (11th Cir. 2015).

${ }^{4}$ In re McWane, Inc., 2014 FTC LEXIS 28, 2014-1 Trade Cas. $(\mathrm{CCH})$ P78,670 (F.T.C. Jan. 30, 2014).
} 
government limits on competition. At the same time, such dialogue is also too tolerant of private restrictions on competition and attests to the need for a more balanced perspective. Government action-through renewed enforcement of antitrust laws and other competition rules-is critical to protecting markets against privately erected barriers to competition.

\section{THE GREAT RECESSION AND THE FEDERAL GOVERNMENT’S RESPONSE}

The bursting of the housing bubbles in many nations and the consequent financial crisis in September 2008 shook the global economy. In late 2008, we appeared to be on the verge of a second Great Depression. Rising house prices had previously allowed people to borrow against their home equity to finance the purchase of a new car or higher education for their children. Due to the evaporation of trillions of dollars in housing wealth, ${ }^{5}$ consumer spending experienced a sharp decline ${ }^{6}$ and private investment collapsed. ${ }^{7}$ The abrupt fall in the annual demand for goods and services - a $\$ 1.2$ trillion decline in the United States alone ${ }^{8}$-had devastating effects. Millions of people around the world lost their jobs and had to obtain public assistance. For Americans, not only could they no longer use their housing wealth to fund consumption and investment, but more than four million families would lose their homes through bank foreclosures in the coming years. ${ }^{9}$

With the fall 2008 bailouts and ongoing government support protecting the large banks from failure, President Obama, upon taking office, declared that reviving the American economy was his highest priority. Congress passed the American Recovery and Reinvestment Act, colloquially known as "the stimulus," which provided $\$ 800$ billion to prop up demand in the U.S. economy. ${ }^{10}$ Given the weak state of the economy six years later, the value of the stimulus remains disputed in popular debate. Among economists, however, there is broad consensus that the stimulus helped revive the economy and averted a much worse catastrophe. ${ }^{11}$ Only the government was in a position to compensate for the collapse in private spending and put the unemployed millions back to work.

\footnotetext{
${ }^{5}$ Roger C. Altman, The Great Crash, 2008, ForeIGn AfFAIRS (Jan. 2009), available at https://www.foreignaffairs.com/articles/united-states/2009-01-01/great-crash-2008.

${ }^{6}$ Graph: Personal Consumption Expenditures, ECONOMIC RESEARCH: FEDERAL RESERVE BANK OF ST. LOUIS (2015), http://research.stlouisfed.org/fred2/graph/?id=PCE.

${ }^{7}$ Graph: Net Domestic Investment: Private: Domestic Business, ECONOMIC ResEARCH: FEDERAL RESERVE BANK OF ST. LOUIS (2015), http://research.stlouisfed.org/fred2/graph/ ?id=W790RC1Q027SBEA.

${ }^{8}$ Dean Baker, Obama's Stimulus Failure, GUARDIAN (Dec. 19, 2011), http://www.theguardian.com/commentisfree/cifamerica/2011/dec/19/obama-stimulusfailure-dean-baker.

${ }^{9}$ More U.S. Home Foreclosures Competed in March, ReUTERs (Apr. 30, 2013), http://www.reuters.com/article/2013/04/30/usa-housing-corelogicidUSL2N0DG1JS20130430.

${ }^{10}$ American Recovery and Reinvestment Act of 2009, Pub. L. No. 111-5, 123 Stat. 115, 208; Christina D. Romer, The Fiscal Stimulus, Flawed but Valuable, N.Y. TimeS, Oct. 20, 2012, available at $\mathrm{http} / / / \mathrm{www}$.nytimes.com/2012/10/21/business/how-the-fiscal-stimulushelped-and-could-have-done-more.html?_r=0.

${ }^{11}$ Justin Wolfers, What Debate? Economists Agree the Stimulus Lifted the Economy, N.Y. TiMES (July 29, 2014), http://www.nytimes.com/2014/07/30/upshot/what-debateeconomists-agree-the-stimulus-lifted-the-economy.html?smid=tw-share\&_r $=2$.
} 
The stimulus law included a controversial Buy American provision. This rule, subject to select narrow exceptions, required federally financed construction projects, for instance, to use domestic concrete and steel. ${ }^{12}$ Federal contractors generally had to buy American goods even when imports were substantially cheaper. Some criticized this requirement as "protectionist" and claimed it undermined global free trade. ${ }^{13}$ The Economist even compared Buy American to the infamous Smoot-Hawley Tariff of $1930,{ }^{14}$ which (supposedly) made the Great Depression much worse. ${ }^{15}$

Despite the negative reaction from some quarters, Buy American had macroeconomic logic and was overall desirable in a deeply depressed economy. The U.S. government spent nearly a trillion dollars on stimulus, and ran a deficit of close to $\$ 1.5$ trillion in 2009. ${ }^{16}$ Buy American directed the government's extraordinary spending toward domestic producers and helped put unemployed individuals and idle factories in the United States back to work. Paul Krugman wrote in February 2009 that without Buy American, "[m]y fiscal stimulus helps your economy, by increasing your exports - but you don't share in my addition to government debt." ${ }^{\prime 17}$ American voters would have been justified in asking: Why should the government take on large amounts of additional debt to help workers in Germany-instead of workers in the United States? And even from the narrow perspective of "economic efficiency," the gains from domestically focused fiscal stimulus likely swamped the losses from mildly protectionist trade practices. ${ }^{18}$

\section{MCWANE PROTECTS ITS MONOPOLY}

With the stimulus disbursing billions for water and other infrastructure projects, the Buy American requirement created a problem in one manufacturing segment: iron pipefittings. Pipefittings connect the thousands of miles of high-pressure pipe that provide us with clean water. They are at the heart of a largely invisible - but essential-system. After decades of losing market to low-cost imports from Brazil, China, and India, most domestic manufacturers of iron pipefittings had gone out of business. Only one company, McWane, still had domestic manufacturing capacity. As a result, the stimulus law temporarily conferred a monopoly on the company. When it came to iron pipefittings, Buy American meant Buy McWane.

${ }^{12}$ American Recovery and Reinvestment Act of 2009, Pub. L. No. 111-5, § 1605, 123 Stat. $115,303$.

${ }^{13}$ Daniella Markheim, Buy American Hurts America, Heritage Foundation (Jan. 30, 2009), http://www.heritage.org/research/reports/2009/01/buy-american-hurts-america.

${ }^{14}$ Trade Policy: Buying American, ECONOMIST (Jan. 29, 2009), available at http://www.economist.com/node/13031019.

${ }^{15}$ The Battle of Smoot-Hawley, ECONOMIST (Dec. 18, 2008), available at http://www.economist.com/node/12798595.

${ }^{16}$ Graph: Federal Government Budget Surplus or Deficit, ECONOMIC RESEARCH: FEDERAL RESERVE BANK OF ST. LOUIS, http://research.stlouisfed.org/fred2/graph/ ?id=M318501A027NBEA.

${ }^{17}$ Paul Krugman, Protectionism and Stimulus, N.Y. TIMES (Feb. 1, 2009, 4:47 PM), http://krugman.blogs.nytimes.com/2009/02/01/protectionism-and-stimulus-wonkish/.

${ }^{18}$ The Nobel Prize-winning economist James Tobin captured this idea in economic terms as "[I]t takes a heap of Harberger triangles [economic loss from protectionism] to fill an Okun gap [losses from unemployment]." James Tobin, How Dead is Keynes?, 15 ECON. INQUIRY 459, 468 (1977). 
Fortunately, McWane's monopoly did not seem destined to last for long. Soon after the stimulus was passed, other suppliers recognized a big opportunity and swung into action. Because these competitors had relied exclusively on foreign foundries up until then, they had to establish a domestic manufacturing presence to capture a share of the stimulus pot. They had three options: (1) build a foundry from scratch, (2) purchase an existing foundry, or (3) contract with an independent foundry that produced pipefittings as well as other iron products. The third route would be the most expedient but would not allow new entrants to produce fittings as efficiently as McWane. Independent contracting has several disadvantages, including "less specialized and efficient equipment; smaller batch sizes; [and] additional logistical costs associated with inventory, finishing, and freight." ${ }^{19}$ To compete effectively with McWane, rivals would need to operate their own facilities.

Just as rivals sensed an attractive opportunity, McWane recognized the threat to its monopoly in domestic fittings and feared that its margins would "get[] creamed" ${ }^{20}$ by the competition. If competitors successfully entered the market, they could undercut McWane's prices. Purchasers of pipefittings would have some choice and not have to accept monopolistic terms. Instead of enjoying the life of a quiet (and well-rewarded) monopolist, McWane would have to compete to retain business and sacrifice profits in the process.

As the Federal Trade Commission found in a February 2014 decision, ${ }^{21}$ upheld by the Eleventh Circuit, McWane moved quickly to smother the emerging competition and perpetuate its monopoly. Pipefittings are sold almost exclusively through dealers. These distributors offer "one-stop shopping" for contractors, municipalities, and others involved in the construction and maintenance of waterworks. Due to the substantial advantages of selling through dealers, direct sales are generally infeasible. McWane used this industry structure to its advantage. It gave dealers an ultimatum: carry only McWane's domestic fittings or face painful consequences. The penalties would be a denial of future access to McWane's fittings and also a forfeiture of rebates that dealers had earned on past purchases.

Because of the lack of competition, distributors had little choice. McWane already produced a full line of pipefittings whereas the new domestic competitors, at least initially, could offer only a partial line. Stick with the established monopolist or throw one's lot with a fledgling newcomer? It was not a difficult decision for distributors. McWane used its existing monopoly power to compel its distributors to forsake budding rivals.

With distributors acquiescing to its demand not to carry the products of rivals, McWane's strategy proved successful. Two companies that had considered entering the domestic fittings market opted against doing so in the face of McWane preemptively blocking access to distribution paths. The one company that did enter, Star, was effectively marginalized. Star obtained a small market share due to two events: a minor exception in McWane's distribution policy, and McWane terminating a national distributor after one of its local branches decided to carry Star's fittings.

\footnotetext{
${ }^{19}$ In re McWane, Inc., 2014 FTC LEXIS 28, 2014-1 Trade Cas. (CCH) P78,670, *70 (F.T.C. Jan. 30, 2014).

${ }^{20} I d$. at $* 88$.

${ }^{21}$ Id. at $* 118$.
} 
With this limited market access, Star could not build the sales volumes necessary to operate its own pipefittings foundry. It had to rely instead on higher cost, nonspecialized independent foundries and was severely hobbled in its competition against McWane. By depriving Star and other potential rivals of sufficient dealer outlets, McWane effectively nipped the competitive threat in the bud and maintained its monopoly power.

\section{THE MCWANE MATTER: The InTERsection of Public And PRivate ECONOMiC Power}

McWane's monopolization of the domestic iron pipefittings industry is the result of two efforts to create closed markets - one public, one private. Through the Buy American provision in the fiscal stimulus, the federal government excluded foreign competitors from an important market for goods. This policy prohibited Asian, European, and other firms abroad from competing to supply federal contracts worth billions of dollars in 2009 and 2010. Even though it was protectionist, Buy American provided public benefits during a depression. It channeled the government's deficit spending toward the employment of Americans.

Following the enactment of Buy American, McWane erected a protective wall around its newfound monopoly. The company used its power as the sole domestic incumbent to compel dealers into carrying only its products and foreclose competition. It closed wholesale distribution channels to nascent competitors. McWane's exclusionary conduct, unlike Buy American, had no offsetting benefits. McWane extracted private wealth from the public purse. Because of McWane's successful monopolization, the federal government indirectly paid more for domestic iron pipefittings than it would have in a competitive market.

When evaluating the role of the state in the market, it must be remembered that the market is not a realm of "natural order." The government enacts and enforces the regulations necessary for markets to exist. Among other things, the legal machinery creates property rights, enforces contracts, and defines tortious conduct, and in so doing establishes the groundwork for market exchange. Bernard Harcourt succinctly demolishes the "naturalism of the market" fallacy: "The idea of a selfregulated market is preposterous ... [and] would be like a competitive sporting event without a referee: it would not work, nor has it ever worked."22

In shaping markets, government at all levels routinely restricts the scope of competition. Buy American is hardly a unique case of positive government restriction on competitive markets. For instance, child labor, minimum wage, and product safety laws, by design, restrain market competition and advance important social goals. Children are not allowed to work full-time jobs even though this proscription violates an abstract commitment to "competition" in the labor market. State and federal law also prohibit the sale of shoddy, unsafe products, notwithstanding that prohibitions on, say, cars with exploding gas tanks limit competition in goods markets and may raise consumer prices. As these examples show, government limitations on competition are sometimes essential for promoting the general welfare. And even regulations that restrict the growth of emerging technologies are not always undesirable. These rules can, for example,

\footnotetext{
${ }^{22}$ HARCOURT, supra note 2, at 196.
} 
promote consumer safety and need to be evaluated on a case-by-case basis ${ }^{23}$-not glibly dismissed as archaic and harmful.

To be sure, the public must be on guard against government regulations that enrich well-heeled incumbents. They can and do exist. Congress' dramatic expansion of intellectual property rights in recent decades is a prominent example of powerful private entities using government to restrict competition and sacrifice the public good. ${ }^{24}$ But governmental restrictions on competition are not intrinsically bad. It would be a mistake to assume that all government barriers to competition serve the affluent and well-connected at the expense of everyone else.

At the same time, McWane's anticompetitive conduct is a reminder that vigilance toward private barriers to open markets is essential. Unlike democratic governments, powerful corporations face little public accountability. The business historian Alfred Chandler observed that, due to the rise of large corporations, "the visible hand of management [has] replaced the invisible hand of market mechanisms ${ }^{25}$ in a modern economy. In highly concentrated markets, this visible hand has power not only over present outcomes but can also control the long-term development of an industry. And monopolists and oligopolists exercise their power to advance their own interests, regardless of the consequences for the rest of us. In effect, many modern markets are not competitive but rather governed by private regulatory power.

Health care- a sector that now accounts for 17 percent of the U.S. gross domestic product ${ }^{26}$-illustrates the enormous power of private entities. Hospital chains with monopoly power in local markets are a leading contributor to the exorbitant cost of health care in the United States. ${ }^{27}$ These entities impose massive markups on nearly everything they provide to patients-from Tylenol to chemotherapy. ${ }^{28}$ And they can also use their existing clout to exclude competitors. For example, by restricting insurers from contracting with smaller rival providers, dominant hospitals can foreclose competition and preserve their pricing power. ${ }^{29}$

On the internet, giants like Amazon, Comcast, and Google, already wield

${ }^{23}$ See e.g., Dean Baker, Don't Buy the 'Sharing Economy' Hype: Airbnb and Uber Are Facilitating Rip-Offs, GUARDIAN (May 27, 2014), http://www.theguardian.com/ commentisfree/2014/may/27/airbnb-uber-taxes-regulation.

${ }^{24}$ See, e.g., Amy Kapczynski, Intellectual Property's Leviathan, 77 LAW \& CONTEMP. Probs. 131, 144 (2014) (“[The] 'Mickey Mouse' Copyright Term Extension Act . . . lengthened copyright protection by two decades, not only prospectively but also retroactively (to better incentivize Walt Disney, God rest his soul?).").

${ }^{25}$ Alfred D. Chandler, Jr., The Visible Hand: The Managerial Revolution in AMERICAN BUSINESS 6 (1977).

${ }^{26}$ Health Expenditures, Total, THE WORLD BANK (2013), http://data.worldbank.org/ indicator/ SH.XPD.TOTL.ZS.

${ }^{27}$ See, e.g., Uwe E. Reinhardt, Peter S. Hussey \& Varduhi Petrosyan, It's the Prices Stupid: Why the United States Is So Different from Other Countries, 22 Health AfFaIRs 89, 102 (2003); Clark C. Havighurst \& Barak D. Richman, The Provider Monopoly Problem in Health Care, 89 OR. L. REV. 847, 854-58 (2011).

${ }^{28}$ See generally Steven Brill, Bitter Pill: Why Medical Bills Are Killing Us, TIME (March 4, 2014), available at http://time.com/198/bitter-pill-why-medical-bills-are-killing-us/\#198/ bitter-pill-why-medical-bills-are-killing-us/.

${ }^{29}$ See, e.g., Press Release, Dep't of Justice, Justice Department Reaches Settlement with Texas Hospital Prohibiting Anticompetitive Contracts with Health Insurers (Feb. 25, 2011), available at http://www.justice.gov/opa/pr/justice-department-reaches-settlement-texashospital-prohibiting-anticompetitive-contracts. 
tremendous power over what we buy and view and also have the ability to decide the fate of content providers. They can use their platforms to hobble and even eliminate competitive threats and perpetuate their dominance. Amazon wields tremendous power over the book world, ${ }^{30}$ and can intimidate even very large publishers. ${ }^{31}$ And some have alleged that Amazon has sold popular e-book titles at below-cost prices to maintain its dominance in this new market. ${ }^{32}$ Today, Comcast provides broadband service to approximately 25 percent of Americans - a figure that would have risen to around one-third if the company had been allowed to acquire Time Warner Cable. ${ }^{33}$ Because they must rely on Comcast's broadband bottleneck to reach one-fourth of Americans, content providers and competitors, like Netflix, are effectively at the mercy of the Philadelphia-based cable behemoth. ${ }^{34}$ Google, the dominant search engine in much of the world, can manipulate its algorithm to favor its own services and starve rivals of visibility. ${ }^{35}$ These examples show that economic power is more than just a matter of high prices and can also implicate core values such as the freedom of expression.

Unfortunately, over the past several decades, the Supreme Court has displayed great faith in the beneficence of dominant corporations. On the basis of conservative economic theory, it has established permissive antitrust rules. Whether it is on the question of monopolists dealing with competitors ${ }^{36}$ or engaging in predatory pricing, ${ }^{37}$ the Supreme Court has opted to expand corporate autonomy and abandon antitrust law's historical commitment to keep markets open

\footnotetext{
${ }^{30}$ United States v. Apple Inc., 952 F. Supp. 2d 638, 670 (S.D.N.Y. 2013) ("With nearly a $90 \%$ market share for e-books in 2009, Amazon was the single most important seller of e-books in America, and also a dominant seller of physical books.").

${ }^{31}$ See, e.g., David Streitfeld \& Melissa Eddy, As Publishers Fight Amazon, Books Vanish, N.Y. TIMES (May 23, 2014, 7:24 AM), http://bits.blogs.nytimes.com/2014/05/23/ amazon-escalates-its-battle-against-hachette/ ("The battle is being waged largely over physical books. In the United States, Amazon has been discouraging customers from buying titles from Hachette, the fourth-largest publisher by market share. Late Thursday, it escalated the dispute by making it impossible to order Hachette titles being issued this summer and fall.").

${ }^{32}$ Drew Sandholm, Amazon's 'Predatory Pricing' Questioned, CNBC (June 30, 2014), http://www.cnbc.com/id/101799842\#.

${ }^{33}$ Timothy B. Lee, The Comcast/Time Warner Deal Isn't about Competition. It's about Power., WASH. Post The SwITCH (Feb. 19, 2014), http://www.washingtonpost.com/blogs/ the-switch/wp/2014/02/19/the-comcasttime-warner-deal-isnt-about-competition-its-aboutpower/.

${ }^{34}$ Press Release, Dep't of Justice, Comcast Corporation Abandons Proposed Acquisition of Time Warner Cable After Justice Department and the Federal Communications Commission Informed Parties of Concerns (Apr. 24, 2015), available at http://www.justice.gov/opa/pr/comcast-corporation-abandons-proposed-acquisition-timewarner-cable-after-justice-department; Zachary M. Seward, The Inside Story of How Netflix Came to Pay Comcast for Internet Traffic, QuARTz (Aug. 27, 2014), http://qz.com/256586/ the-inside-story-of-how-netflix-came-to-pay-comcast-for-internet-traffic/.

${ }^{35}$ Frank Pasquale, The Black Box Society: The Secret Algorithms That CONTROL MONEY AND INFORMATION 67-69 (2015).

${ }^{36}$ Verizon Commc'ns, Inc. v. Law Offices of Curtis V. Trinko, LLP, 540 U.S. 398

(2004); Pac. Bell Tel. Co. v. linkLine Commc'ns, Inc., 555 U.S. 438 (2009).

${ }^{37}$ Brooke Group v. Brown \& Williamson Tobacco Corp., 509 U.S. 209 (1993).
} 
and free of private blockades. ${ }^{38}$ Today, powerful businesses have broad freedom to smother competitors and close markets.

Yet, even now, the Supreme Court's conservative antitrust decisions do not necessarily make the monopolistic domination of markets a fait accompli. As $M c$ Wane illustrates, even in this unfavorable legal environment, antitrust enforcers are by no stretch powerless to challenge monopolies. The federal antitrust agencies, the Department of Justice and the Federal Trade Commission, still have the capacity to limit the sweep of bad high court precedents through test cases. Encouragingly, the government and private plaintiffs have obtained favorable lower court rulings on monopolization claims in recent years, and avoided dreaded Supreme Court review. ${ }^{39}$

Public policy, in seeking to protect competitive markets, must go beyond just aggressive enforcement of antitrust law. Sector-specific regulations such as network neutrality ${ }^{40}$ are a vital part of the competition policy regime and are necessary to curtail the power of large corporations. Other important solutions include the creation of public competitors that can discipline incumbent monopolies and oligopolies. ${ }^{41}$

\section{CONCLUSION}

Government restrictions on competition, whether in the market for cars, hotel rooms, or taxicabs, have attracted a great deal of attention of late. As a basic matter, government is not exogenous to the market: a functioning state is, in reality, a precondition for modern markets. Because it establishes the rules necessary for markets to develop and potentially flourish, government unavoidably shapes the bounds and structures of the private economic sphere. And more specifically, public limitations on competition are not intrinsically hostile to the interests of ordinary Americans and can, in fact, advance vital social goals, such as full employment and public safety. Accounting for these considerations, governmental

${ }^{38}$ See, e.g., United States v. Topco Assocs., 405 U.S. 596, 610 (1972) (“Antitrust laws in general, and the Sherman Act in particular, are the Magna Carta of free enterprise. They are as important to the preservation of economic freedom and our free-enterprise system as the Bill of Rights is to the protection of our fundamental personal freedoms. And the freedom guaranteed each and every business, no matter how small, is the freedom to compete- to assert with vigor, imagination, devotion, and ingenuity whatever economic muscle it can muster.").

${ }^{39}$ See, e.g., ZF Meritor, LLC v. Eaton Corp., 696 F.3d 254 (3d Cir. 2012), cert. denied, 133 S. Ct. 2024 (2013); United States v. Dentsply Int'l, Inc., 399 F.3d 181 (3d Cir. 2005), cert. denied, 126 S. Ct. 1023 (2006); Spirit Airlines, Inc. v. Northwest Airlines, Inc., 431 F.3d 917 (6th Cir. 2005), reh'g denied, 2006 U.S. App. LEXIS 10603 (6th Cir. Apr. 13, 2006); LePage's Inc. v. 3M, 324 F.3d 141 (3d Cir. 2003) (en banc), cert. denied, 124 S. Ct. 2932 (2004).

${ }^{40}$ Rebecca R. Ruiz \& Steve Lohr, F.C.C. Approves Net Neutrality Rules, Classifying Broadband Internet Service as a Utility, N.Y. TIMES (Feb. 26, 2015), available at http://www.nytimes.com/2015/02/27/technology/net-neutrality-fcc-vote-internet-utility.html.

${ }^{41}$ See, e.g., Dominic Rushe, Chattanooga's Gig: How One City's Super-Fast Internet Is Driving a Tech Boom, GUARDIAN (Aug. 30, 2014), http://www.theguardian.com/world/2014/ aug/30/chattanooga-gig-high-speed-internet-tech-boom ("Thanks to an ambitious roll-out by the city's municipally owned electricity company, EPB, Chattanooga is one of the only places on Earth with internet at speeds as fast as 1 gigabit per second-about 50 times faster than the US average."). 
restraints should not be blindly condemned as harmful; rather, they should be examined on a case-by-case basis. Even aggressive newcomers with savvy public relations (such as Airbnb, Tesla, and Uber) and giddy talk of "disruption" should not lead us to denounce legal restrictions on these actors as a matter of reflex.

Critically, the present focus on public restraints should not mean that private efforts to create closed markets get a free pass. In contrast to democratic public authorities, large corporations face little accountability. Dominant firms can use predatory and other exclusionary methods to maintain their long-run supremacy and prosper through exploitation of the public. Given the awesome power of monopolistic and oligopolistic corporations, antitrust enforcers and other regulators must reassert public discipline over private empires. 